\title{
Effect of Operating Parameters on the Electrocoagulation of Simulated Acid Dyebath Effluent
}

\author{
I. Arslan-Alaton*, I. Kabdaşlı and Y. Şahin
}

Department of Environmental Engineering, Faculty of Civil Engineering, Istanbul Technical University, Maslak, Istanbul, Turkey

\begin{abstract}
The present study investigates the influence of operating parameters (electrolyte concentration, applied electrical current, initial reaction $\mathrm{pH}$ ) on color and COD removals from a simulated acid dyebath effluent employing electrocoagulation with aluminum (Al) and stainless steel (SS) electrodes. Our results indicated that almost complete (100\% for EC with SS electrodes) color and partial (around 50\% for EC with SS electrodes) COD removal could be achieved via electrocoagulation using $\mathrm{Al}$ as well as SS electrodes once working conditions were optimized. The study also revealed that electrocoagulation with SS electrodes was more attractive both in terms of treatment performance as well as electrical energy and sludge handling costs; the electrical energy requirement and sludge production rate were $17 \mathrm{kWh} /\left(\mathrm{m}^{3}\right.$ wastewater) and $8200 \mathrm{~g} /\left(\mathrm{m}^{3}\right.$ wastewater) for electrocoagulation with $\mathrm{Al}$ electrodes, instead of $8 \mathrm{kWh} /\left(\mathrm{m}^{3}\right.$ wastewater $)$ and 700 $\mathrm{g} /\left(\mathrm{m}^{3}\right.$ wastewater $)$ for electrocoagulation with SS electrodes to achieve the same treatment efficiency.
\end{abstract}

Key Words: Textile wastewater, acid dyebath effluent, electrocoagulation, aluminum and stainless steel electrodes, operating conditions, COD and color removal.

\section{INTRODUCTION}

Wastewater generated by textile dyeing and finishing activities is known to contain considerable amounts of biologically difficult to degrade or even refractory dyes and dye auxiliaries, making its efficient treatment a rather difficult task. So far, several biochemical, chemical and physical treatment methods were applied to treat textile wastewater, however, with limited success [1-4]. More recently, studies have focused on color and chemical oxygen demand (COD) removal from real combined textile wastewater and reactive dyebath effluent $[5,6]$ as well as aqueous textile dyes [7-10] using electrocoagulation (EC). EC has successfully been employed for the treatment of strong effluents such as electroplating, laundry, slaughterhouse and chemical industry wastewater [11]. Results have demonstrated that pollution parameters can be effectively removed via EC provided that operating conditions were carefully optimized and feasibility studies were conducted. Considering that the main operating costs associated with the EC treatment process are electrical energy requirements and sludge handling, it is very important to assess these two economical parameters before proposing EC as an alternative treatment option for dyehouse effluent. Until now, electrical energy requirements of EC were addressed in only few studies. By taking into account the necessity of $\mathrm{pH}$ adjustment for the usually extremely alkaline dyehouse effluent, it seems to make more sense to apply the EC process to high-strength, low-volume and slightly acidic effluent from the polyamide dyeing operations where acid dyes and their respective dye auxiliaries (wetting agents, $\mathrm{pH}$ buffers) are used. Moreover, as mentioned pre-

*Address correspondence to this author at the Department of Environmental Engineering, Faculty of Civil Engineering, Istanbul Technical University, Maslak, Istanbul, Turkey; Tel: 009021228537 86; Fax: 009021228565 45; E-mail: arslanid@itu.edu.tr viously, there is only one case study available in the scientific literature dealing with the treatment of real exhausted dyebath [5], however, electrocoagulation of acid dyebath effluent has never been reported so far.

Considering that efficient and economic treatment of real dyebath effluent rather than combined textile wastewater streams or aqueous solutions of single dyes is a more realistic way of dealing with textile wastewater management issues, in the present study the treatability of a simulated acid dyebath effluent with EC using aluminum (Al) and stainless steel (SS) electrodes was investigated. In the first part of the experimental work, the effect of varying operating parameters such as electrolyte concentration, initial reaction $\mathrm{pH}$ and current density was assessed, in the second part, electrical energy requirements and sludge production rates associated with the process were determined for optimized working conditions.

\section{MATERIALS AND METHODOLOGY}

\section{Simulated Acid Dyebath Effluent}

All experiments were conducted with simulated acid dyebath effluent (called "ADE" herein) that were prepared by dissolving proper amounts of acid dye formulations and their corresponding dye assisting chemicals in hot $(\mathrm{T}=60$ $70{ }^{\circ} \mathrm{C}$ ) distilled deionized water. All dyes and dye auxiliaries were kindly supplied by a local dyehouse and used as received. The ingredients of the simulated acid dyebath are given in Table $\mathbf{1}$, whereas Table $\mathbf{2}$ presents their environmental characterization in terms of average color (absorbance), COD and original $\mathrm{pH}$.

\section{Electrocoagulation Experiments}

The electrocoagulation unit consisted of a $1500 \mathrm{~mL}$ capacity polyethylene (P.E.100) reactor $($ length $=34.3 \mathrm{~cm}$; 
Table 1. Composition of the Simulated Acid Dyebath Effluent

\begin{tabular}{|c|c|c|c|}
\hline Acid Dyes & $\begin{array}{c}\text { Concentration } \\
(\mathbf{m g} / \mathbf{L})\end{array}$ & Acid Dye Auxiliaries & $\begin{array}{c}\text { Concentration } \\
(\mathbf{m g} / \mathbf{L})\end{array}$ \\
\hline \hline Telon Yellow AR01* & 30 & Ruco Acid (Acid donor) & 500 \\
Acid Red 336 & 30 & Laugal TP (Equalizer) & 1500 \\
Acid Blue 264 & 30 & \\
\hline
\end{tabular}

*Commercial name; color index number not known.

width $=12.5 \mathrm{~cm}$; height $=28.3 \mathrm{~cm}$ ) equipped with six monopolar, parallel connected electrodes (304 grade stainless steel or aluminum) used as both anode and cathode materials. The effective surface area of the electrodes was 38.5 $\mathrm{cm}^{2}$. The electrode dimensions were $11.9 \mathrm{~cm}$ (length) and $1.02 \mathrm{~cm}$ (diameter). The distance between the electrodes was fixed as $2 \mathrm{~mm}$. The applied current and voltage in the electrocoagulation unit was maintained by means of a high precision direct current power supply.

Table 2. Environmental Characterization of the Simulated Acid Dyebath Effluent

\begin{tabular}{|l|c|}
\hline \multicolumn{1}{|c|}{ Parameter } & Average Value \\
\hline \hline COD $(\mathrm{mg} / \mathrm{L})$ & 2700 \\
\hline COD contribution of acid dyes $(\mathrm{mg} / \mathrm{L})$ & $<100$ \\
\hline Color, in absorbance units $(1 / \mathrm{cm}), @$ & \\
$-436 \mathrm{~nm}$ & 0.856 \\
$-525 \mathrm{~nm}$ & 0.585 \\
$-620 \mathrm{~nm}$ & 0.274 \\
\hline Original acid dyebath $\mathrm{pH}$ & 3.56 \\
\hline
\end{tabular}

\section{Analytical Procedures}

The process parameters being followed during electrocoagulation experiments were $\mathrm{pH}$, color (absorbance) and COD. All samples being subjected to electrocoagulation were first settled for $30 \mathrm{~min}$ and thereafter filtered through 0.45 micron Millipore filters prior to COD and color measurements. The absorbance of the untreated and treated ADE samples was measured on a Pharmacia KB - Novaspec II model colorimeter at $436 \mathrm{~nm}, 525 \mathrm{~nm}$ and $620 \mathrm{~nm}$ wavelengths representing yellow, red and blue colors according to German environmental legislations [12] in $1 \mathrm{~cm}$ glass cuvettes, since no color discharge limits exist in Turkey yet. In order to avoid data replication and confusion, only absorbance data recorded at $436 \mathrm{~nm}$, e.g. the dominant absorption band of the studied dyebath effluent was presented herein.

The COD of untreated and treated ADE was measured according to ISO 6060 [13]. The amount of sludge (metal hydroxide precipitate + removed textile dyebath ingredients) produced after electrocoagulation was determined by measuring the suspended solids content of ADE after being subjected to electrocoagulation under optimized reaction conditions in accordance with Standard Methods [14] upon filtration of the sample aliquots through 1.2 micron glass fiber filters.
In former studies different electrolytes were investigated for electrochemical treatment of textile dyes and wastewater $[15,16]$. In the present work, however, $\mathrm{NaCl}$ was employed as the sole electrolyte, due to the fact that our preliminary studies indicated that during electrocoagulation using $\mathrm{Al}$ and $\mathrm{SS}$ electrodes in the presence of $\mathrm{Na}_{2} \mathrm{SO}_{4}$ electrolyte, color as well as COD abatement rates were seriously retarded.

\section{RESULTS AND DISCUSSIONS}

\section{Working with Al Electrodes}

\section{Effect of Electrolyte Concentration}

It is believed that the main pollutant removal mechanism observed during electrocoagulation is adsorption and entrapment onto the amorphous aluminum hydroxide precipitate formed due to the anodic reaction at maximum rate at pH 6-7 [17];

$$
\mathrm{Al}(\mathrm{s}) \rightarrow \mathrm{Al}^{3+}(\mathrm{aq})+3 \mathrm{e}^{-}
$$

Percent color $\left(\mathrm{A}_{436}\right)$ and COD removal efficiencies observed during electrocoagulation (applied electrical current $10 \mathrm{~A}$; initial $\mathrm{pH}=7.0$ ) of $\mathrm{ADE}$ at varying $\mathrm{NaCl}$ (electrolyte) concentrations is presented in Fig. (1 (a) and (b)), respectively. As is evident in Fig. (1), increasing the electrolyte concentration from $0.5 \mathrm{~g} / \mathrm{L}$ to $1.0 \mathrm{~g} / \mathrm{L}$ slightly increased color and COD abatement rates (up to $91 \%$ and $36 \%$, respectively), and a further addition of $\mathrm{NaCl}$ up to $3 \mathrm{~g} / \mathrm{L}$ resulted in a moderate but significant retardation of treatment efficiencies both in terms of color and COD removals.

A similar trend was also obvious for sludge formation that reached its highest value of $8200 \mathrm{mg} / \mathrm{L}$ in the presence of $1.0 \mathrm{~g} / \mathrm{L} \mathrm{NaCl}$, whereas the lowest sludge production rates were found at the highest and lowest electrolyte concentrations. From these findings it is evident that color and COD removal efficiencies were related with the amount of solid aluminum hydroxide formed during electrocoagulation. As expected, the reaction $\mathrm{pH}$ continuously increased from 7 to around 9-10 after $30 \mathrm{~min}$ electrocoagulation due to cathodic $\mathrm{OH}^{-}$production [18];

$$
2 \mathrm{H}_{2} \mathrm{O}+2 \mathrm{e}^{-} \rightarrow \mathrm{H}_{2}(\mathrm{~g})+2 \mathrm{OH}^{-}
$$

A kinetic evaluation was undertaken for color and COD abatement rates obtained during electrocoagulation using $\mathrm{Al}$ (as well as SS) electrodes. From data evaluation it was concluded that color and COD abatement rates observed throughout the investigated reaction period did not follow any conventional kinetic model (1st, or even pseudo-first order kinetics) and hence no kinetic model could be applied to the color and COD abatement profiles. 


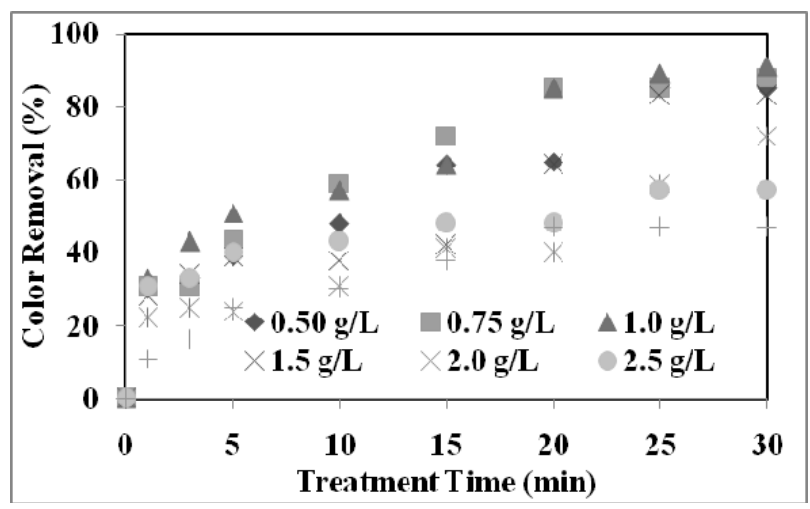

(a)

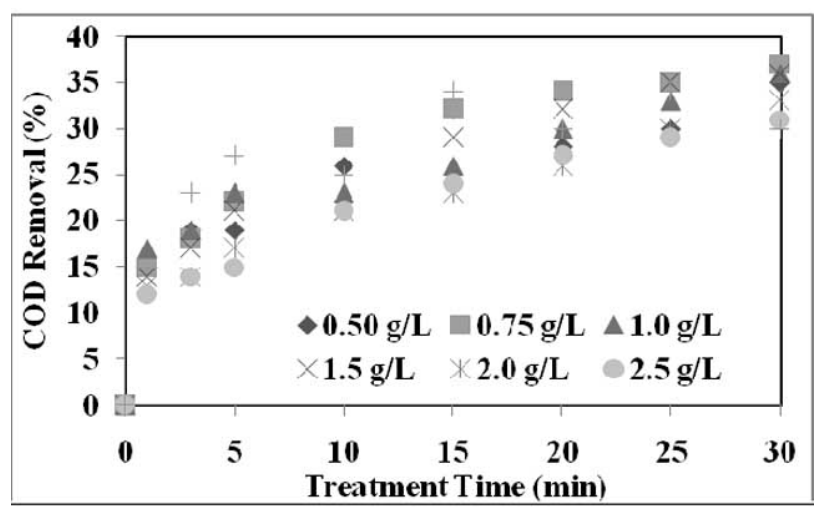

(b)

Fig. (1). Effect of $\mathrm{NaCl}$ concentration on percent color (a) and COD (b) removal efficiencies obtained during electrocoagulation using $\mathrm{Al}$ electrodes.

\section{Effect of Applied Electrical Current}

Fig. (2 (a) and (b)) depicts changes in color and COD removal efficiencies during electrocoagulation (Electrolyte concentration $=1000 \mathrm{mg} / \mathrm{L} \mathrm{NaCl}$; initial $\mathrm{pH}=7.0$ ) under different applied electrical currents, respectively. It is known that electrical current density is the major operating variable directly affecting electrocoagulation performance and operating costs. From the above figure it is clear that increasing the applied current from 2.5 to $12.5 \mathrm{~A}$ appreciably improved decolorization and COD removal rates from 41 and $94 \%$ (for color) to 18 and $42 \%$ (for COD), respectively. Parallel to the applied current, sludge production rates increased immensely from $1800 \mathrm{mg} / \mathrm{L}$ at $2.5 \mathrm{~A}$ up to $10400 \mathrm{mg} / \mathrm{L}$ for $12.5 \mathrm{~A}$.

Formation of huge amounts of chemical sludge can be considered as the main obstacle of electrocoagulation using Al electrodes that has to be carefully outweighed against the improved treatment efficiency obtained at elevated currents. Hence, it was decided to conduct further experiments to elucidate the effect of initial reaction $\mathrm{pH}$ under the following operating conditions; applied current $=10 \mathrm{~A}$; electrolyte concentration $=1000 \mathrm{mg} / \mathrm{L} \mathrm{NaCl}$.

\section{Effect of Initial pH}

Former related studies have already demonstrated that the optimum $\mathrm{pH}$ of in-situ $\mathrm{Al}(\mathrm{OH})_{3}$ floc formation takes place at slightly acidic to neutral $\mathrm{pH}(5.5-7.0)$, where $\mathrm{Al}(\mathrm{OH})_{3}$ solubility reaches its lowest value. Fig. (3) displays the effect of varying the initial electrocoagulation $\mathrm{pH}$ from 3.5 to 9.5 on color (a) and COD (b) removal rates. A bit surprisingly, it was observed that color and COD removal efficiencies as well as sludge formation rates were not very different from each other, although it was anticipated that percent treatment efficiencies would be slightly better when the $\mathrm{pH}$ was below 7.0 .

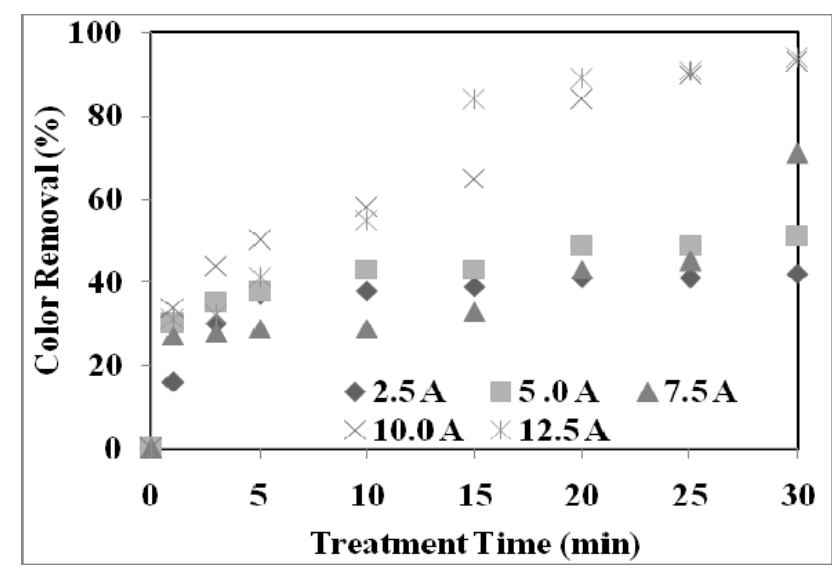

(a)

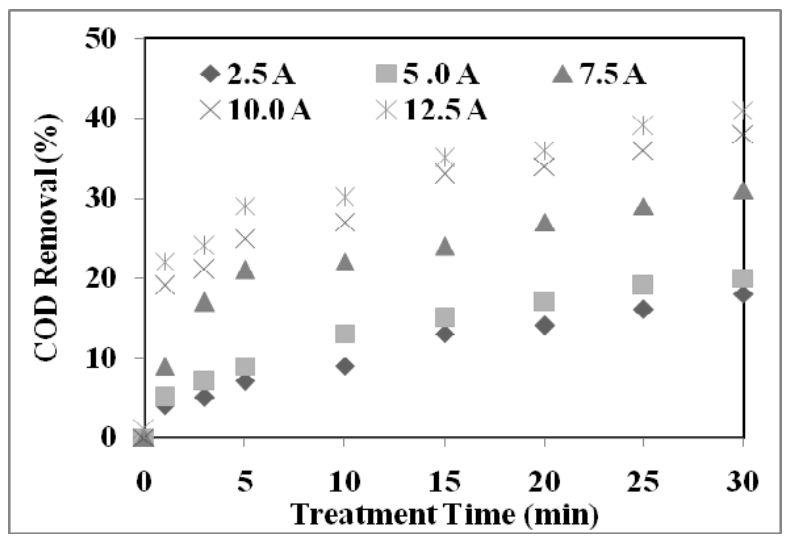

(b)

Fig. (2). Effect of applied electrical current on percent color (a) and COD (b) removal efficiencies obtained during electrocoagulation using $\mathrm{Al}$ electrodes.

Due to the fact that removal efficiencies both in terms of color and COD were high and the final effluent $\mathrm{pH}$ remained below 9 , the optimum initial $\mathrm{pH}$ was established as $\mathrm{pH}=7.0$.

\section{Working with SS Electrodes}

\section{Effect of Electrolyte Concentration}

Fig. (4) gives changes in percent color (a) and COD (b) removal efficiencies as a function of $\mathrm{NaCl}$ concentration during electrocoagulation with $\mathrm{SS}$ electrodes (initial $\mathrm{pH}=$ 7.5; applied current $=10 \mathrm{~A}$ ). From Fig. (4) it is evident that increasing the electrolyte concentration from $0.5 \mathrm{~g} / \mathrm{L}$ to 1.5 $\mathrm{g} / \mathrm{L}$ increased the color as well as COD abatement rates significantly; a further increase of electrolyte concentration did not improve, but even slightly inhibited removal efficiencies both in terms of color and COD's. The increase in electrolyte concentration from $0.5 \mathrm{~g} / \mathrm{L}$ to $3.0 \mathrm{~g} / \mathrm{L}$ also resulted in an in- 
crease of ferric hydroxide sludge formation from $170 \mathrm{mg} / \mathrm{L}$ to $740 \mathrm{mg} / \mathrm{L}$, respectively. Generally speaking, sludge formation was much less than in the case of electrocoagulation

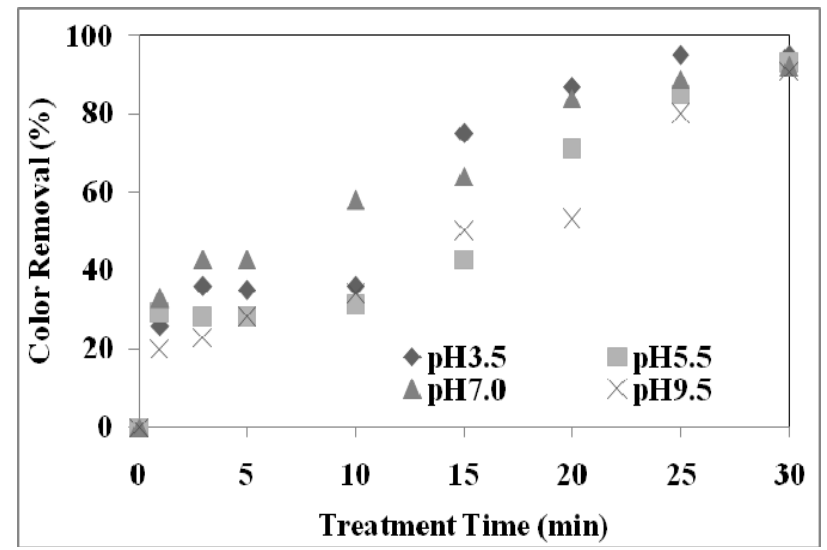

(a)

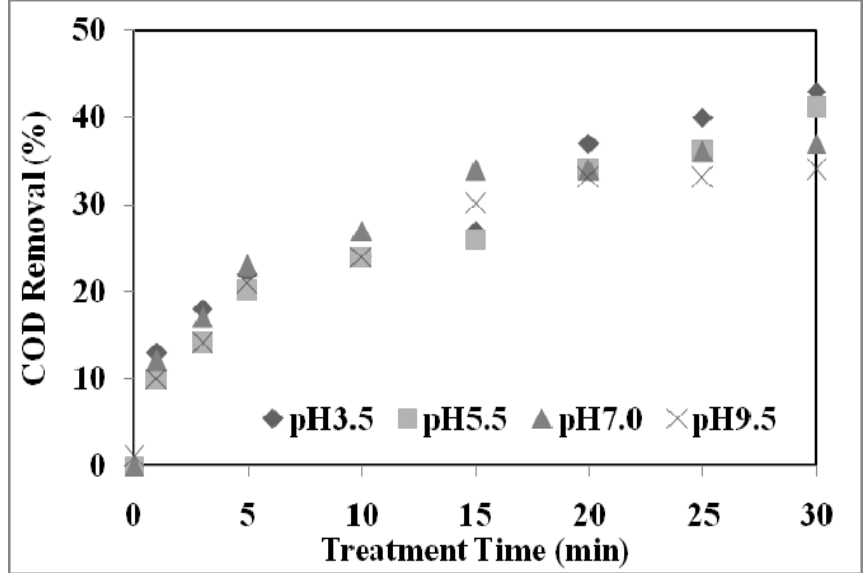

(b)

Fig. (3). Effect of initial reaction $\mathrm{pH}$ on percent color (a) and COD (b) removal efficiencies obtained during electrocoagulation using Al electrodes.

with $\mathrm{Al}$ electrodes and at the same time, the $\mathrm{pH}$ during electrocoagulation employing SS electrodes also did not increase during the reaction as it proceeded. It rather slightly varied in the range of 6.3 to 8.0 throughout the reaction that can speculatively explained as follows; the acid dyebath effluent contained an acid donor that was easily oxidizable and started to release an acid upon degradation of the acid donor's original structure. Acid release on the other hand hinders the $\mathrm{pH}$ increase usually expected during electrocoagulation. Degradation of the acid donor is only possible under the reducing environment of electrocoagulation with SS electrodes where ferric iron is reduced to ferrous iron thereby oxidizing the acid ester. During electrocoagulation with SS electrodes, the reducing environment is easily brought about within the first period of electrocoagulation due to oxygen depletion during oxidation of ferrous iron to ferric iron [19];

$$
\mathrm{Fe}^{2+}+2 \mathrm{H}_{2} \mathrm{O}+\mathrm{O}_{2}(\mathrm{~g}) \rightarrow 4 \mathrm{Fe}(\mathrm{OH})_{3}(\mathrm{~s})+8 \mathrm{H}^{+}
$$

Hence, when SS electrodes are employed reaction mechanisms other than adsorption-absorption-particle entrapment may play an important role in color and COD removal from ADE. Similar to the trend of electrocoagulation conducted with $\mathrm{Al}$ electrodes, elevating the electrolyte concentration from $0.5 \mathrm{~g} / \mathrm{L}$ to $1.0 \mathrm{~g} / \mathrm{L}$ resulted in an appreciable acceleration of color as well as COD abatement rates, and an increase of $\mathrm{NaCl}$ concentration up to $3.0 \mathrm{~g} / \mathrm{L}$ did not considerably improve decolorization and COD removal rates.

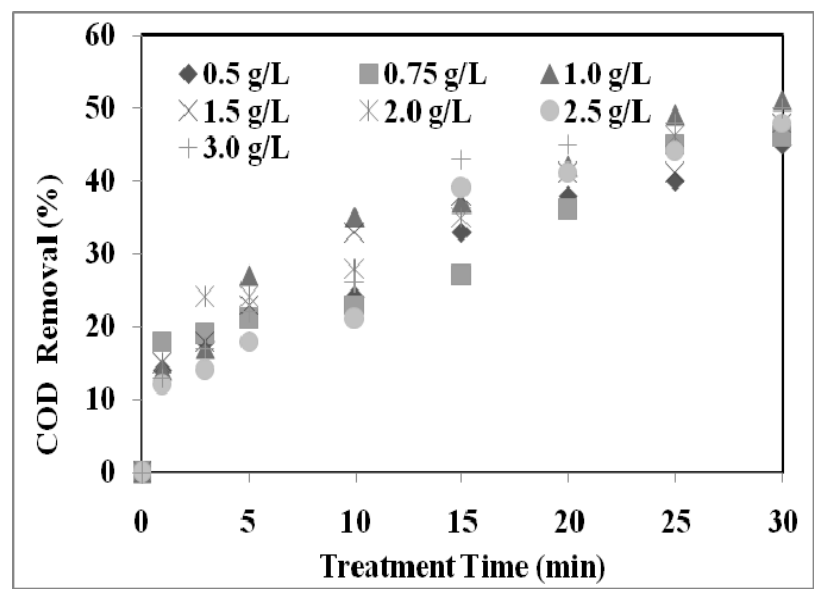

(a)

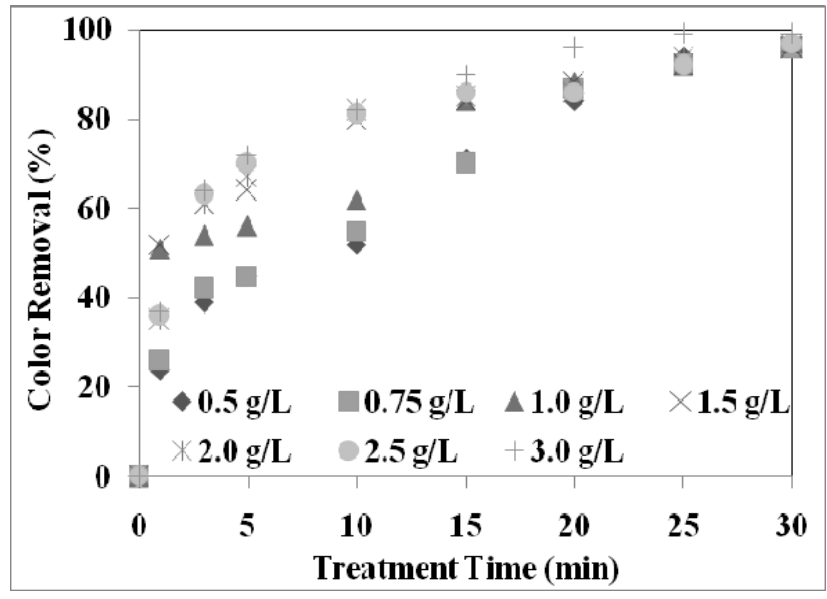

(b)

Fig. (4). Effect of $\mathrm{NaCl}$ concentration on percent color (a) and COD (b) removal efficiencies obtained during electrocoagulation using SS electrodes.

Hence, for the next series of experimental runs performed at varying electrical currents and initial $\mathrm{pH}$ 's, the electrolyte concentration was selected as $3000 \mathrm{mg} / \mathrm{L} \mathrm{NaCl}$ for maximum treatment performance.

\section{Effect of Applied Electrical Current}

Fig. (5) shows the time-dependent changes in color (a) and COD (b) removal efficiencies as a function of treatment time under varying applied electrical currents. From the figure it is apparent that increasing the applied current from $2 \mathrm{~A}$ to 20 A significantly increased color (from $58 \%$ to $100 \%$ ) as well as COD (32\% to 58\%) abatement rates. More than $95 \%$ decolorization could be achieved even after 20 min electro- 
coagulation above an electrical current of $10 \mathrm{~A}$. The increase in sludge formation was not as dramatic as in the case of electrocoagulation using $\mathrm{Al}$ electrodes; increasing the current density from $2 \mathrm{~A}$ to $20 \mathrm{~A}$ increased the sludge formation rate from $650 \mathrm{mg} / \mathrm{L}$ to $1.0 \mathrm{~g} / \mathrm{L}$ revealing that electrocoagulation with SS electrodes although run at $3.0 \mathrm{~g} / \mathrm{L}$ in the presence of $\mathrm{SS}$ electrodes instead of $1.0 \mathrm{~g} / \mathrm{L}$ electrolyte concentration in the presence of $\mathrm{Al}$ electrodes, might be preferred to electrocoagulation using $\mathrm{Al}$ electrodes due to the fact that considerably higher color as well as COD removal efficiencies can be achieved at higher currents thereby producing less chemical sludge.

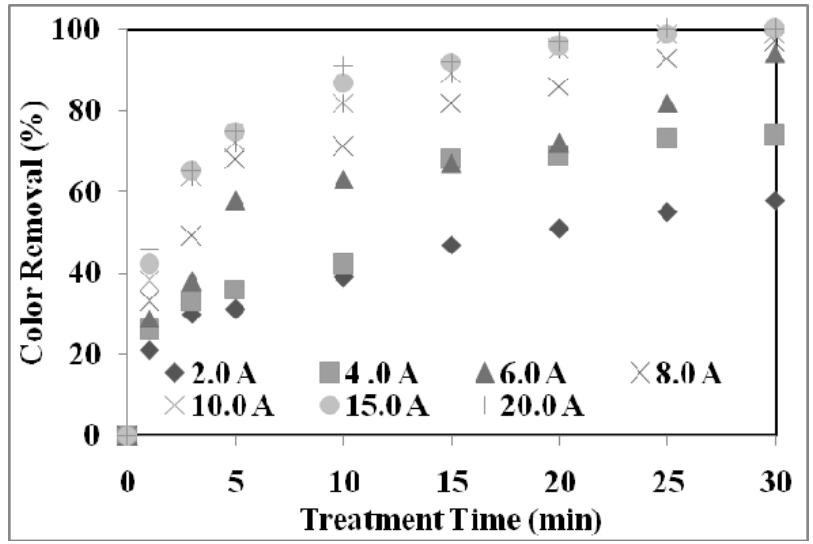

(a)

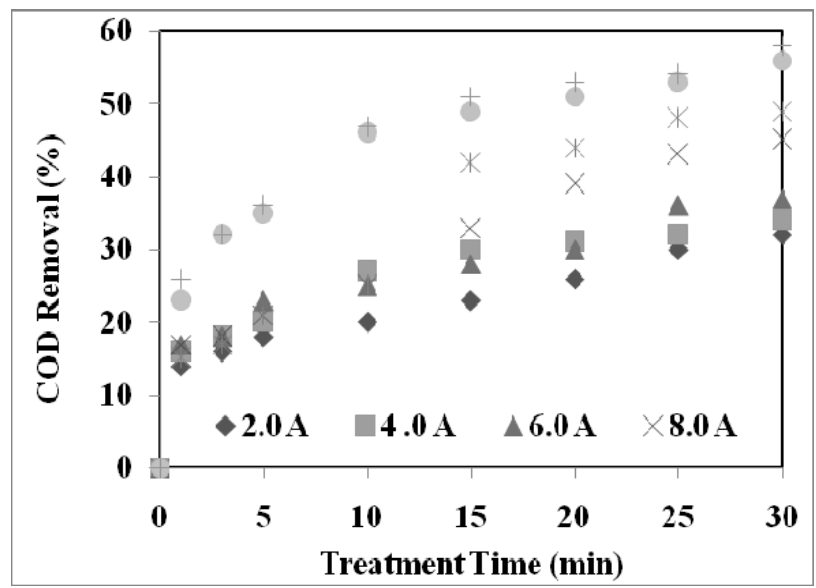

(b)

Fig. (5). Effect of applied electrical current on percent color (a) and COD (b) removal efficiencies obtained during electrocoagulation using SS electrodes.

Again, due to continuous acid release that occurred as a consequence of acid donor degradation during electrocoagulation with SS electrodes, the $\mathrm{pH}$ did not increase during the reaction. Instead, the $\mathrm{pH}$ fluctuated between 7 and 8 throughout electrocoagulation as it progressed. It was decided to run the next electrocoagulation experiments with SS electrodes at an optimized electrical current of $10 \mathrm{~A}$.

\section{Effect of Initial $\mathrm{pH}$}

The effect of initial $\mathrm{pH}$ on percent color and COD removal efficiencies obtained during electrocoagulation using
SS electrodes is given in Fig. (6 (a) and (b)), respectively. From the above figure it is obvious that with exception of the experimental run conducted at an initial $\mathrm{pH}$ of 7.5 , percent COD removal efficiency remained below $40 \%$ and decolorization in the range of $80-94 \%$ (for $\mathrm{A}_{436}$ ) when the initial $\mathrm{pH}$ was 3.5, 5.5 and 9.5. It may also be important to note here that the sludge production after $30 \mathrm{~min}$ electrocoagulation starting at an initial $\mathrm{pH}$ of 7.5 was $700 \mathrm{mg} / \mathrm{L}$ but only $200-$ $270 \mathrm{mg} / \mathrm{L}$ after $30 \mathrm{~min}$ electrocoagulation run at an initial $\mathrm{pH}$ of 3.5, 5.5 and 9.5. Obviously, there was a positive relationship between the amount of sludge formed and percent color and COD removed. Highest percent color and COD removal efficiencies were obtained under the following experimental working conditions: Applied electrical current $=10 \mathrm{~A}$; electrolyte concentration $=3000 \mathrm{mg} \mathrm{NaCl} / \mathrm{L}$ for complete $(100 \%)$ color and partial (51\%) COD reduction.

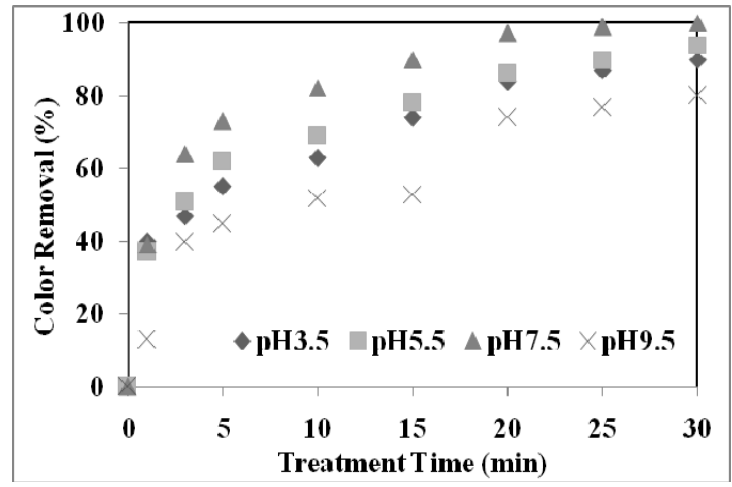

(a)

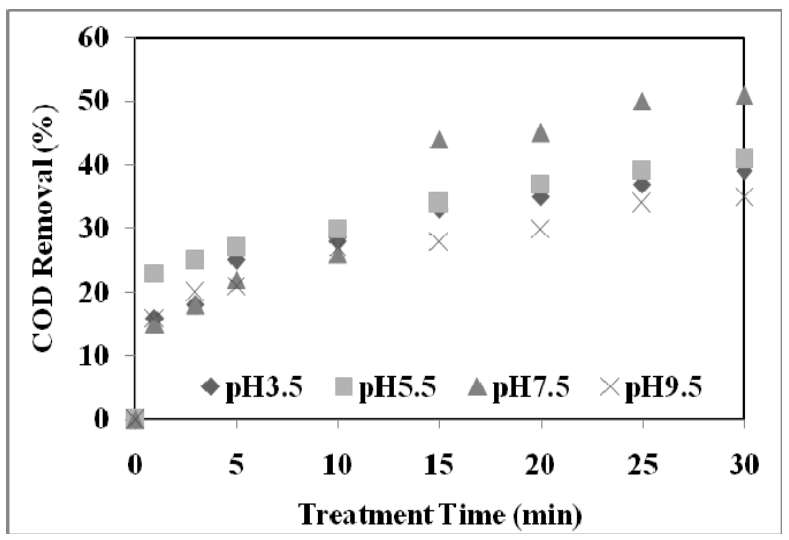

(b)

Fig. (6). Effect of initial reaction $\mathrm{pH}$ on percent color (a) and COD (b) removal efficiencies obtained during electrocoagulation using SS electrodes.

\section{Comparison of Sludge Production Rates}

Fig. (7) demonstrates the significant difference in sludge production rates between $30 \mathrm{~min}$ electrocoagulation of acid dyebath effluent employing Al and SS electrodes. From the figure it is clear that management costs associated with sludge disposal would tremendously reduce when SS is preferred as the electrode material for acid dyebath effluent treatment. The surprisingly low sludge formation rates ob- 
served for electrocoagulation using SS electrodes may speculatively be explained by complex species formation of the in-situ formed ferrous iron by the deprotonated acid hindering the production of ferrous and ferric hydroxide sludge, provided that the $\mathrm{pK}_{\mathrm{a}}$ value of the released acid is below 4-5.

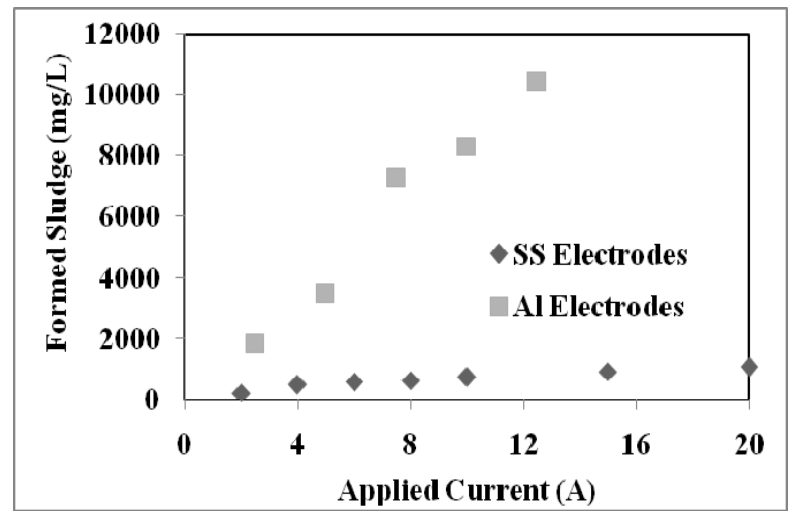

Fig. (7). Sludge formation after $30 \mathrm{~min} \mathrm{EC}$ at varying applied electrical currents (Working conditions: $\mathrm{pH}_{0}: 7.0$ and $1.0 \mathrm{~g} \mathrm{NaCl} / \mathrm{L}$ for $\mathrm{Al}$ electrodes; $\mathrm{pH}_{0}: 7.5$ and $3.0 \mathrm{~g} \mathrm{NaCl} / \mathrm{L}$ for $\mathrm{SS}$ electrodes)

\section{Economic Considerations}

As mentioned before, for estimation of operating costs for $\mathrm{EC}$ using $\mathrm{Al}$ or SS electrodes electrical energy requirement and sludge formation rates have to be calculated. In the present study, EC with $\mathrm{Al}$ and SS electrodes were compared under optimized working conditions. 30 min $\mathrm{EC}$ with $\mathrm{Al}$ was required to achieve $91 \%$ color and $36 \%$ COD removals from 1.5 liters ADE, whereas almost the same treatment efficiencies could be reached via EC with SS in only $15 \mathrm{~min}$. Corresponding electrical energy requirements to achieve $90 \%$ color and $40 \%$ COD removals after EC were calculated for an applied electrical current of $10 \mathrm{~A}$ (average potential $=5$ V) for a treatment period of $30 \mathrm{~min}$ with $\mathrm{Al}$ and $15 \mathrm{~min}$ with SS electrodes. Since electrical energy requirements are a direct function of treatment time, EC with $\mathrm{Al}$ resulted in two-fold electrical energy consumption $\left(17 \mathrm{kWh}\right.$ per $\mathrm{m}^{3}$ wastewater) as compared with EC using SS electrodes (8 $\mathrm{kWh}$ per $\mathrm{m}^{3}$ wastewater). Electrical energy requirements change from country to country but indirectly reflect the main operating costs of EC treatment systems.

\section{CONCLUSIONS AND RECOMMENDATIONS}

Electrocoagulation (EC) is one of the most promising, emerging alternative treatment methods that have more recently been applied for the treatment of industrial wastewaters. In the present study acid dyebath effluent (ADE) was simulated and treated via electrocoagulation using aluminum and stainless steel electrodes under different operating conditions. Results have shown that color and COD removal efficiencies as well as sludge production rates were affected by applied electrical current, electrolyte concentration and initial reaction $\mathrm{pH}$. EC with $\mathrm{Al}$ electrodes was capable of almost complete (around 90\%) color accompanied with almost $40 \%$ COD abatement, whereas EC with SS resulted in complete color removal and 50\% COD abatement. Inspection of changes in $\mathrm{pH}$ during EC and suspended solids concentrations obtained after EC experiments gave a further insight into the underlying reaction mechanisms involved in EC; removal of color and COD was thought to be mainly adsorption of pollutants onto aluminum hydroxide sludge, whereas in the case of EC with SS electrodes, the pollutant abatement mechanism was speculatively a combination of adsorption, absorption, particle entrapment as well as redox reaction initiated by the reducing environment occurring at the electrode functioning as the anode of the process. Considering the treatment performance (electrical energy consumption) as well as sludge formation rates observed during the optimization experiments, EC using SS electrodes can be recommended for effective and economic treatment of ADE.

\section{ACKNOWLEDGEMENTS}

The authors thank Dr. Izzet Alaton (Turbo Tekstil A.Ş.) for supplying the reactive dyestuffs and dye auxiliary chemicals. The present work was financially supported by TUBA (The Turkish Academy of Sciences) under the GEBIP Scholarship Program.

\section{REFERENCES}

[1] Kabdaşlı I, Arslan-Alaton I, Vardar B, Tünay O. Comparison of electrocoagulation, coagulation and the Fenton process for the treatment of reactive dyebath effluent. Wat Sci Technol 2007; 55(10): 125-134.

[2] Arslan-Alaton I. A review of the effect of dye assisting chemicals on advanced oxidation of reactive dyes in wastewater. Color Technol 2003; 199: 345-353.

[3] Tünay O, Kabdaşlı NI, Eremektar G, Orhon D. Color removal from textile wastewaters. Wat Sci Technol 1996; 34(11): 9-16.

[4] Kabdaşlı N, Tünay O, Artan R, Orhon D. Acrylic dyeing wastewaters characterization and treatability. Proceedings of the Third International Conference on Appropriate Waste Management Technology for Developing Countries, February 25-26 2005, Nagpur, India, pp. 239-248.

[5] Arslan-Alaton I, Kabdaşlı I, Hanbaba D, Kuybu E. Electrocoagulation of a real reactive dyebath effluent using aluminum and stainless steel electrodes. J Haz Mater 2008; 150: 166-173.

[6] Kobya M, Can OT, Bayramoglu M. Treatment of textile wastewaters by electrocoagulation using iron and aluminum electrodes. J Haz Mater 2003; B100: 163-178.

[7] Kobya M, Demirbaş E, Can OT, Bayramoğlu, M. Treatment of Levafix Orange textile dye solution by electrocoagulation. J Haz Mater 2006; B132: 183-188.

[8] Golder AK, Hridaya N, Samanta AN. Electrocoagulation of methylene blue and eosin yellowish using mild steel electrodes. J Haz Mater 2005; 127(1-3): 134-140.

[9] Daneshvar N, Sorkhabi HA, Kasiri MB. Decolorization of dye solution containing Acid Red 14 by electrocoagulation with a comparative investigation of different electrode connections. J Haz Mater 2004; B112: 55-62.

[10] Mollah MYA, Pathak SR, Patil PK, Vayuvegula M, Agrawal TS, Gomes JAG, Kesmez M, Cocke DL. Treatment of orange II azo dye by electrocoagulation (EC) technique in a continuous flow cell using sacrificial iron electrodes. J Haz Mater 2004; B109: 165-171.

[11] Mollah MYA, Schennah R, Parga JR, Cocke DR. Electrocoagulation (EC)-science and applications. J Haz Mater 2001; B84: 29-41.

[12] Gähr F, Hermanutz F, Oppermann W. Ozonation: an important technique to comply with new German laws for textile wastewater treatment. Wat Sci Technol 1994; 30: 255-263.

[13] ISO 6060. Water Quality-Determination of the Chemical Oxygen Demand. TC 147/SC 2, Geneva, 1989.

[14] APHA-AWWA-WPCF. Standard methods for the examination of water and wastewater. 20th Ed. American Public Health Association, Washington DC, 1998.

[15] Manisankar P, Rani C, Viswanathan S. Effect of halides in the electrochemical treatment of distillery effluent. Chemosphere 2004; 57(8): 961-966. 
[16] Fernandes A, Morao A, Magrinho M, Lopes A, Gonçalves I. Electrochemical degradation of C. I. Acid Orange 7, Dyes Pigments 2004; 61: 287-296.

[17] Mollah MYA, Morkovsky P, Gomes JAG, Kesmez M, Parga J, Cocke DL. Fundamentals, present and future perspectives of electrocoagulation. J Haz Mater 2004; B114: 199-210.
[18] Li X, Cui Y, Feng Y, Xie Z, Gu J. Reaction pathways and mechanisms of the electrochemical degradation of phenol on different electrodes. Wat Res 2005; 39: 1972-1981.

[19] Reife A, Freeman HS. Environmental Chemistry of Dyes and Pigments. John Wiley \& Sons, Inc., Canada 1996; p. 329-330. 